\title{
Aerosols over the Foothills of the Eastern Himalayan Region during Post-monsoon and Winter
}

Aerosol and Air Quality Research

\section{Seasons}

\section{Sishir Dahal ${ }^{1,2^{*}}$, Dipesh Rupakheti ${ }^{3}$, Ram Kumar Sharma4, Binod Kumar Bhattarai ${ }^{4}$, Bhupesh Adhikary ${ }^{1 *}$}

\author{
${ }^{1}$ International Centre for Integrated Mountain Development, Khumaltar, Lalitpur, Nepal \\ ${ }^{2}$ Department of Civil Engineering, Pulchowk Campus, Institute of Engineering, Tribhuvan \\ University, Lalitpur, Nepal \\ ${ }^{3}$ Jiangsu Key Laboratory of Atmospheric Environment Monitoring and Pollution Control, \\ Collaborative Innovation Center of Atmospheric Environment and Equipment Technology, \\ School of Environmental Science and Engineering, Nanjing University of Information Science \\ and Technology, Nanjing 210044, China \\ ${ }^{4}$ Department of Applied Sciences and Chemical Engineering, Pulchowk Campus, Institute of \\ Engineering, Tribhuvan University, Lalitpur, Nepal
}

\section{ABSTRACT}

In this study a Microtops II sunphotometer is used for the first time over Birtamode, a rapidly growing city located in the eastern Himalayan foothills of Nepal, to measure aerosol optical depth (AOD). The average AOD for the observation period (October 2018-February 2019) was $0.68 \pm$ 0.39 with the post-monsoon season having a higher value $(0.74 \pm 0.43)$ compared to the winter season $(0.60 \pm 0.32)$. The Angstrom exponent $(\alpha)$ for post-monsoon and winter are found to be $1.08 \pm 0.10$ and $1.11 \pm 0.16$ respectively. During the monitoring period, the majority of AOD values $(47 \%)$ are above 0.60 , indicating moderately polluted conditions in the region. Anthropogenic, biomass burning, and mixed aerosols are identified as the prevalent aerosol types in the study region. The observed aerosol classification is also explained in terms of CAMS near-real-time model datasets. The AOD values retrieved by MODIS, VIIRS, Himawari-8, and CAMS show a good correlation with the observed Microtops $A O D$ with $\mathrm{R}^{2}$ values ranging from 0.60 to 0.94 . Moreover, different MODIS aerosol products (DB, DT, and combined DB-DT) are evaluated based on a comparison of Collection 6.1 AOD with the ground truth obtained from Microtops. The spatial distribution of AOD as observed by various satellites are compared and the vertical distribution of aerosol is also explained with the extinction coefficient provided by the CALIOP lidar onboard CALIPSO and aerosol types provided by CAMS.

Keywords: Microtops II sunphotometer, MODIS, CAMS, Himawari-8, VIIRS, CALIPSO, Eastern Himalayan foothills

\section{INTRODUCTION}

Atmospheric aerosols are the solid particles and liquid droplets suspended in the atmosphere varying between $0.001 \mu \mathrm{m}$ to $100 \mu \mathrm{m}$ in size. These originate from both natural and anthropogenic activities. They are known to have both warming and cooling effects on the atmosphere as they perturb incoming solar radiation and outgoing terrestrial long wave radiation by scattering or absorption. Aerosols perturb radiative forcing indirectly through cloud properties (Penner et al., 2003). Aerosols such as mineral dust and black carbon are identified to cause warming by absorbing solar radiation (Kaufman et al., 2002; Lohmann and Feichter, 2005). The microphysical and chemical properties of atmospheric aerosols strongly influence the direct and indirect effects 
on radiative forcing and cloud microphysics (Hegg et al., 1996). Aerosols play a major role in deteriorating air quality with harmful impacts on human health (Stocker et al., 2013). There is a great spatial and temporal variation in levels, distribution and composition of atmospheric aerosols. Anthropogenic aerosols are of prime importance on a regional scale, although natural aerosols have an indispensable role on a global scale (Kaufman and Fraser, 1983; Ramachandran et al., 2012).

The Indo-Gangetic Plain (IGP) is well known for its dense population and routinely high aerosol concentrations which affect the IGP as well as neighboring regions along the Himalaya foothills, Himalayas, and the Tibetan plateau (Ganguly et al., 2006; Rupakheti et al., 2018). The IGP region has been extensively explored using atmospheric model simulations and satellite observations to evaluate the spatial and temporal variability of aerosol properties (Adhikary et al., 2007; Bibi et al., 2015; Gautam et al., 2011). However, to evaluate the satellite-based measurements and to provide observational constraints for atmospheric models, ground-based observations are needed for validation. Previous studies on aerosol optical properties using satellite observations, and ground-based measurements in the central Himalayas are confined to the AErosol RObotic NETwork (AERONET) sites situated along its foothills. Studies over Kathmandu (Cho et al., 2017; Rupakheti et al., 2019) and Pokhara (Ramachandran and Rupakheti, 2021) illustrate the aerosol optical properties in the central Himalayan foothills. The short-term study conducted by Gautam et al. (2011) reported aerosol optical properties from the foothills of Himalayas (specifically Hetauda, Dhulikhel, and Langtang regions). Several studies of AOD have been reported from the far eastern end of the Himalayas reaching as far west as Dibrugarh, India (Pathak et al., 2012). However, limited observations have been reported from the Himalayan region adjacent to the Bay of Bengal. This zone is where polluted air masses transported across the IGP and outflow from the two megacities of Kolkata and Dhaka (India and Bangladesh respectively) merge. This creates an important pollution hotspot. This region is of critical importance from an aerosol cloud interaction perspective as the Indian summer monsoon jet changes to an easterly direction from southwesterly over this region. Moreover, elevated aerosols have been postulated to impact the duration and intensity of Indian summer monsoon (Lau et al., 2006; Meehl et al., 2008).

In this work, we analyzed the aerosol optical depth (AOD) and Angstrom's parameters ( $\alpha$ and $\beta$ ) for a period from October 2018 to February 2019 at Birtamode, an urban center in the foothills of the eastern Himalayan region. Similarly, we evaluated the model-based AOD products provided by the Copernicus Atmosphere Monitoring Service (CAMS) and satellite products from the Moderate Resolution Imaging Spectroradiometer (MODIS) platform, Visible Infrared Imaging Radiometer Suite (VIIRS), and Himawari-8 Advanced Himawari Imager (AHI). Vertical features of the aerosol layer were explored using Cloud-Aerosol Lidar and Infrared Pathfinder Satellite Observations (CALIPSO) data. The spatial distribution of aerosols over the region were investigated and classified by aerosol type. This study provides information on aerosol distribution and optical properties in the foothills of the eastern Himalaya, an area of limited or no data.

\section{METHODS}

\subsection{Study Area}

Birtamode is the socio-economic hub of one of the most populated districts of Nepal and is situated in the foothills of the eastern Himalaya (see Fig. 1). It is a highly urbanized region located in the Jhapa district, where a significant increase in urban area has occurred (from $27.12 \mathrm{~km}^{2}$ in 2001 to $70.92 \mathrm{~km}^{2}$ in 2016). It has an annual average rainfall of $270 \mathrm{~cm}$ and the temperature ranges between 32 to $35^{\circ} \mathrm{C}$ in summer and between 8 to $15^{\circ} \mathrm{C}$ in winter (Rimal et al., 2017). Though the air quality in Birtamode seems to be deteriorating with the increased urbanization, no targeted studies have been undertaken to investigate the issue. There is no air quality monitoring system in Birtamode with the nearest air quality observatory $85 \mathrm{~km}$ away in the neighboring district. To understand the aerosol properties in the eastern Himalaya, we set up a base station in the Birtamode region $\left(26.65^{\circ} \mathrm{N}, 88^{\circ} \mathrm{E}, 137 \mathrm{~m}\right.$ a.s.I).

\subsection{Instrumentation}

Ground-based spectral AOD was measured from 13 October 2018 to 28 February 2019 at an interval of 30 minutes/ 1 hour from 6:30:00 to 16:30:00 local time (LT) (which is 5 hours 45 minutes 

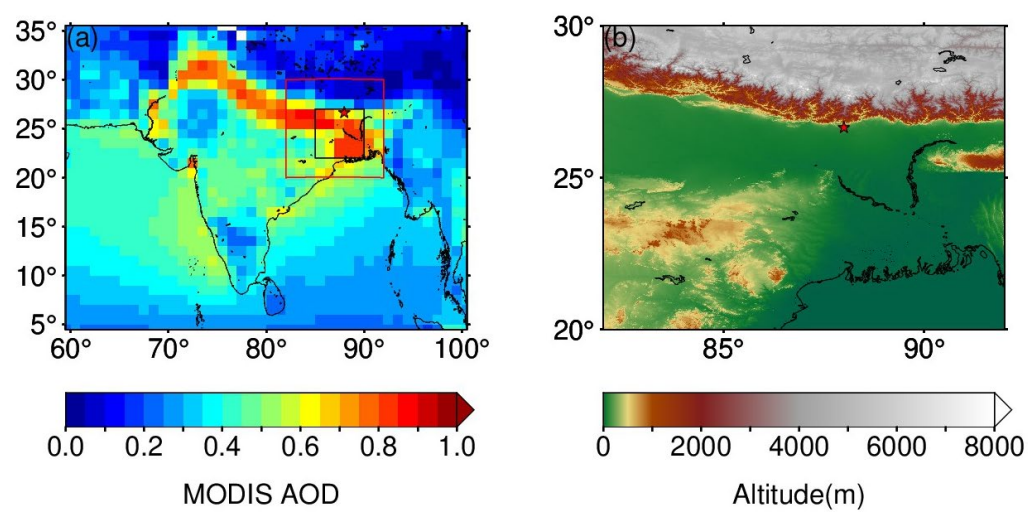

Fig. 1. (a) MODIS AOD (Aqua) (MYD08_M3 v6.1) over south Asia averaged over the period 20132017 and (b) topography map of the region under consideration for satellite/model analysis (The red box in first figure is the area selected for analysis and black box is the domain selected for CALIPSO analysis. The red star is the location for the ground-based measurement site).

ahead of GMT). We used a hand-held Microtops II sunphotometer (manufactured by Solar Light Company Inc., USA) containing five channels at 340, 440, 500, 675, and $870 \mathrm{~nm}$ wavelengths that provide information about the columnar load of aerosols. The $340 \mathrm{~nm}$ channel has a bandwidth of $2 \mathrm{~nm}$, and the other channels have a bandwidth of $10 \mathrm{~nm}$ (Sharma, 2018; Tiwari et al., 2018). The full field of view of the instrument is $2.5^{\circ}$. The details of the working principle of Microtops II instrument have been explained elsewhere (Morys et al., 2001).

Here, we would like to provide a brief overview of the working principle of the instrument. The solar radiation in an atmosphere is greatly influenced by Mie scattering, induced by aerosols, Rayleigh scattering produced by air molecules, and absorption by water vapor and other gaseous molecules (Ichoku, 2002a; Vijayakumar and Devara, 2012). The instantaneous solar radiation intensity, I, reaching the ground and that at the top of the atmosphere, $\mathrm{l}_{0}$ is related by BougerLambert-Beer law as:

$I=I_{0} e^{-\tau^{*}(\lambda) m}$

where $\tau^{*}(\lambda)$ is the total aerosol optical depth, and $m$ is the optical air mass, which is a relative path that the light travels in a slant path and is given by secant of the zenith angle (Pawar et al., 2012; Vijayakumar and Devara, 2012).

AOD at each wavelength is estimated from $\tau^{*}(\lambda)$ by subtracting the contributions due to the Rayleigh scattering and absorption at each wavelength. Spectral AOD and $\alpha$ are the primary parameters for the calculation of columnar aerosol properties; particularly, $\alpha$ contains information about the fraction of the fine versus coarse-mode particles (Schuster et al., 2006) and can be retrieved with Angstrom's power law (Ångström, 1964):

$\tau(\lambda)=\beta \lambda^{-\alpha}$

$\ln [\tau(\lambda)]=-\alpha \ln (\lambda)+\ln (\beta)$

where $\tau(\lambda)$ is the estimated AOD at the wavelength $\lambda, \alpha$ is the Angstrom exponent and $\beta$ is the turbidity coefficient. The value of $\alpha$ and $\beta$ obtained in this study are calculated in the wavelength interval of 340-870 $\mathrm{nm}$ by applying the least square method to Eq. (3).

\subsubsection{MODIS}

The MODIS instruments onboard the Terra and Aqua satellites have been observing the earth since 2000 and 2002 respectively (Remer et al., 2013). The equator crossing times for Terra and Aqua are 10:30 and 13:30 local solar time (LST) respectively. The instrument records spectral radiance in 36 channels with the resolution varying between $250 \mathrm{~m}$ to $1 \mathrm{~km}$ (Levy et al., 2007). 
The MODIS aerosol products are based on three operational algorithms. These are Deep Blue (DB) over land, Dark Target (DT) over land, and DT over ocean. The enhanced DB algorithm is a modification of the DB algorithm that retrieves AOD values over both dark and bright surfaces. The algorithm uses the surface reflectance values at $0.412,0.47$, and $0.65 \mu \mathrm{m}$ channels and estimates the AOD values based on the pre-calculated reflectance values in a lookup table (Hsu et al., 2013). The DT algorithm is prepared separately for ocean and land. Over the land surface, the DT algorithm utilizes surface reflectance at $0.47,0.66,0.86,1.24$, and $2.11 \mu \mathrm{m}$ channels to retrieve AOD. The $1.38 \mu \mathrm{m}$ channel is used for cloud masking. AOD is retrieved at $10 \mathrm{~km}$ and $3 \mathrm{~km}$ resolutions which aggregate $20 \times 20$ and $6 \times 6$ half $\mathrm{km}$ pixels respectively. Based on the reflectance value at $0.66 \mu \mathrm{m}$, the retrieval algorithm removes the darkest $20 \%$ and brightest $50 \%$ of pixels (Remer et al., 2013). The collection 6.1 (C6.1) AOD products have been used in this study as they are better compared to the collection 6 (C6) products (Wei et al., 2019) due to the application of modified surface parameterization, which incorporates the urban surface properties (Gupta et al., 2016). Similar to the C6 AOD products, the C6.1 AOD products also contain the merged DB-DT AOD values, which provide information for all transition regions with variable brightness. These AOD values are based on the MODIS NDVI value and include DT and DB AOD of superior quality obtained by applying the associated quality flags (Mhawish et al., 2017).

\subsubsection{Himawari-8 AHI}

The Advanced Himawari Imager ( $\mathrm{AHI}$ ) is installed on the geostationary earth-orbiting satelliteHimawari-8 which provides dynamic monitoring of the atmosphere for the Asia-Pacific region. The Japanese Aerospace Exploration Agency (JAXA) P-Tree data repository system provides access to Level 2 (L2) and Level 3 (L3) products that give the information of full disk at $500 \mathrm{~nm}$ with temporal resolution of 10 minutes and 30 minutes respectively. $L 2 A O D$ is based on five $A H I$ bands $(470,510,600,800$, and $1600 \mathrm{~nm}$ ) (Fukuda et al., 2013). L3 AOD is a product obtained by processing L2 AOD and has two variables, AOD_Pure and AOD_Merged. AOD_Pure is obtained by removing cloudy pixels from L2 AOD, whereas, AOD_Merged is obtained by interpolating of AOD_Pure (Kikuchi et al., 2018). The data is accessible through ftp server after registering to JAXA Himawari Monitor P-Tree System (https://www.eorc.jaxa.jp/ptree/registration_top.html).

\subsubsection{VIIRS}

The Visible Infrared Imaging Radiometer Suite (VIIRS) is installed on the Suomi National Polar Orbiting Partnership (SNPP) satellite. SNPP is part of the environmental satellite system under operation by the Joint Polar Satellite System (JPSS) (Huang et al., 2016). The VIIRS aerosol products are derived at a spatial resolution of $0.75 \mathrm{~km}$ in the spectral region between $412 \mathrm{~nm}$ and $2250 \mathrm{~nm}$ (Jackson et al., 2013) aggregated to $6 \mathrm{~km}$ (i.e., $8 \times 8$ pixels). The VIIRS retrieval algorithm is based on the MODIS AOD retrieval algorithm architecture. The VIIRS aerosol product is available for download at the LAADS DAAC platform (https://ladsweb.modaps.eosdis.nasa.gov/).

\subsubsection{CAMS}

The Copernicus Atmosphere Monitoring Service (CAMS) is a component of the European Union's Earth observation program, Copernicus, which disseminates information about the Earth's environment based on modeling, satellite observations, and in-situ measurement data. CAMS uses the Integrated Forecasting System (IFS) of the European Centre for Medium-Range Weather Forecasts (ECMWF). The IFS defines the sources of five tropospheric aerosols viz. dust, black carbon, organic, sea-salt, and sulfate aerosols, and incorporates five removal mechanisms viz. dry deposition, sedimentation, conversion of hydrophobic to hydrophilic $\mathrm{BC}$ and $\mathrm{OM}$, transformation of $\mathrm{SO}_{2}$ to $\mathrm{SO}_{4}$, and wet deposition. A detailed description of the IFS mechanism is provided elsewhere (Morcrette et al., 2009). The near-real-time data available at 0 UTC and 12 UTC was used in this study. The data is available for download at the ECMWF data platform (https://apps.ecmwf.int/ datasets/data/cams-nrealtime/levtype=sfc/).

\subsubsection{CALIPSO}

The Cloud-Aerosol Lidar and Infrared Pathfinder Satellite Observations (CALIPSO) flies in a sunsynchronous orbit carrying the Cloud-Aerosol Lidar with Orthogonal Polarization (CALIOP) instrument, 
which crosses the equator at $2 \mathrm{pm}$ and has a repeat cycle of 16 days. CALIOP receives backscatter signals at $532 \mathrm{~nm}$ and $1064 \mathrm{~nm}$, and the profiles are available at a vertical resolution of $30 \mathrm{~m}$ and $60 \mathrm{~m}$ for altitudes below $8.2 \mathrm{~km}$ and between $8.2 \mathrm{~km}$ and $20.2 \mathrm{~km}$ respectively (Winker et al., 2013). The Level 2 aerosol vertical profile data (APro) was used to prepare the vertical profile of $532 \mathrm{~nm}$ Extinction Coefficient $\left(b_{\text {ext }}\right)$. The data has a horizontal resolution of $5 \mathrm{~km}$ and was acquired from the data subsetter web app (https://subset.larc.nasa.gov/calipso/index.php).

\subsection{Error Analysis}

To avoid cloud contamination, Microtops measurements were undertaken on clear days or in instances when clouds were not occluding the solar disk. Once collated, any extremely high values suspected to have been affected by undetected cirrus clouds were removed. Also, AOD values beyond daily mean $\pm 2 \times$ standard deviation were discarded as outliers from further analysis. Inaccuracies in the fit of Angstrom's formula lead to curvature effect in the retrieved spectral AOD values. The comparison of $\alpha$ values obtained using different methods is used to minimize this effect. Hence, $\alpha$ values obtained from the linear fit method (LFM, use of five wavelengths) are correlated with those obtained from the Volz method (VM, use of two extreme wavelengths).

In this study, the CALIPSO data was averaged for the black box highlighted in Fig. 1. For the quality screening of the data, the cloud aerosol discrimination score (CAD_Score), extinction uncertainty (Extinction_Coefficient_Uncertainty_532), and extinction quality control flag of $532 \mathrm{~nm}$ (Extinction_QC_flag_532) were used. Features with a CAD_Score greater than -80 were removed and those layers which have a higher confidence that they are aerosols were retained. Only data (bext values) with Extinction_QC_Flag_532 values between 0 and 1 were used. Retrievals with an extinction coefficient of $99.9 \mathrm{~km}^{-1}$ were also removed following the method described by Winker et al. (2013).

\subsection{Data and Collocation Strategy}

This study being the first of its kind for the eastern Himalaya foothills region, MODIS aerosol products available with both the operational algorithms (DT and DB) were evaluated against ground-based observations. Moreover, the aerosol products provided by other polar orbiting and geostationary satellites and the CAMS model were also evaluated. The products selected and the quality filters used are tabulated in Table 1 . As the timings of satellite overpass and the Microtops measurement don't match exactly, the collocation of these two types of data requires a spatiotemporal window (Jethva et al., 2019). The spatiotemporal collocation ensures that the air mass observed by the satellite sensors/model over the study region is also considered by the ground-based observations, which reduces the representation errors (More et al., 2013; Schutgens et al., 2017). Previous validation studies of MODIS aerosol products have used the spatiotemporal approach presented by Ichoku (2002b). In this study, we compare satellite AOD values averaged over a $0.3^{\circ} \times 0.3^{\circ}$ grid box surrounding the ground station with the ground-based AOD averaged

Table 1. Satellite and model datasets used in this study.

\begin{tabular}{|c|c|c|c|}
\hline Data & Scientific Data Sets (SDS) & Resolution & Contents \\
\hline \multirow[t]{3}{*}{$\begin{array}{l}\text { Terra / MOD04_L2 \& } \\
\text { Aqua / MYD04_L2 }\end{array}$} & $\begin{array}{l}\text { Deep_Blue_Aerosol_Optical_Depth_550_Land_ } \\
\text { Best_Estimate }\end{array}$ & $10 \mathrm{~km}$ & $A O D$ of $Q A F \geq 2$ over land \\
\hline & Optical_Depth_Land_And_Ocean & & $\begin{array}{c}\text { AOD of QAF }=3 \text { over land and } \\
\text { QAF }=1 \text { to } 3 \text { over ocean }\end{array}$ \\
\hline & AOD_550_Dark_Target_Deep_Blue_Combined & & $\begin{array}{l}\text { AOD of QAF = } 1 \text { to } 3 \text { over land } \\
\text { and ocean }\end{array}$ \\
\hline $\begin{array}{l}\text { Terra / MOD04_3K \& } \\
\text { Aqua / MYD04 3K }\end{array}$ & Optical_Depth_Land_And_Ocean & $3 \mathrm{~km}$ & $\begin{array}{c}\text { AOD of QAF }=3 \text { over land and } \\
\text { QAF }=1 \text { to } 3 \text { over ocean }\end{array}$ \\
\hline VIIRS / AERDB_L2 & $\begin{array}{l}\text { Aerosol_Optical_Thickness_550_Land_Ocean_ } \\
\text { Best_Estimate }\end{array}$ & $6 \mathrm{~km}$ & Quality filtered AOD \\
\hline Himawari-8 / AHI & AOT & 0.05 degrees & $\begin{array}{l}\text { Level } 2 \text { AOD at } 500 \mathrm{~nm} \text { and } \\
10 \text { min temporal resolution }\end{array}$ \\
\hline CAMS & aod550 & 0.25 degrees & Total AOD at $550 \mathrm{~nm}$ \\
\hline
\end{tabular}


within \pm 30 min of MODIS and VIIRS overpass. Since Himawari-8 AHI has a higher temporal resolution of $10 \mathrm{~min}$, the $A H I A O D$ is averaged in the time window of \pm 30 min of ground-based observations. CAMS near-real-time analysis provides data at only two time-periods of 0 UTC and 12 UTC. So, daily averaged CAMS AOD is compared with the daily averaged ground observation. As the sunphotometer does not have the $550 \mathrm{~nm}$ channel, AOD values at $550 \mathrm{~nm}$ are calculated using Eq. (3).

To evaluate the uncertainty in the aerosol algorithms, the relative mean bias (RMB), the rootmean square error (RMSE), the mean absolute error (MAE), and the square of the Pearson correlation coefficient $\left(\mathrm{R}^{2}\right)$ are used. $\mathrm{RMB}$ values greater than 1 indicate overestimation whereas the RMB value less than 1 indicates the underestimation of $A O D$ retrievals.

$$
\begin{aligned}
& R M B=\overline{A O D}_{\text {satellite } / \text { model }} /{\overline{A O D_{\text {ground }}}}_{R M S E}=\sqrt{\frac{1}{n} \sum_{i=1}^{n}\left(A O D_{(\text {satellite/model }) i}-A O D_{(\text {gorund }) i}\right)^{2}} \\
& M A E=\frac{1}{n} \sum_{i=1}^{n}\left|A O D_{(\text {satellite/model }) i}-A O D_{(\text {gorund }) i}\right|
\end{aligned}
$$

\section{RESULTS AND DISCUSSION}

\subsection{Synopsis of AOD, $\alpha$, and $\beta$}

Fig. 2 shows the variation of Microtops $A D_{500}$ (unless otherwise stated, Microtops derived $A O D$ hereafter refers to $A O D_{500}$ ), $\alpha_{340-870}$ (unless otherwise stated, $\alpha$ here refers to $\alpha_{340-870}$ ), and

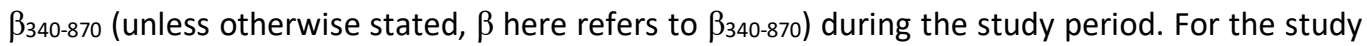
duration, AOD ranges between 0.13 and 1.93 with a mean value of $0.68 \pm 0.39$. Similarly, $\alpha$ values range between 0.34 and 1.49 with a mean value of $1.09 \pm 0.13$. $\beta$ values range between 0.07 and 1.10 with a mean value of $0.30 \pm 0.18$. This variation in AOD, $\alpha$, and $\beta$ is due to differing atmospheric conditions driven by seasonal meteorology as well as changes in sources and types of aerosol emissions over the IGP (Tiwari et al., 2018, 2016). Moreover, the seasonal average value of $\beta$ shows that the aerosol loading during post-monsoon $(0.33 \pm 0.19)$ is higher compared to winter $(0.27 \pm$ 0.16), which is contrary to the results obtained from the central Himalayan foothills region, Pokhara (Regmi et al., 2020). The $\beta$ values show significant correlation $\left(R^{2}=0.964\right)$ with AOD and anticorrelation with $\alpha$ on majority of the days during study period.

The maximum recorded value of AOD during this study for October with the highest standard deviation is attributed to higher AOD values and variation during an observed haze episode. The percentage of total number of days with AOD and $\alpha$ values greater than the measured mean values are $42 \%$ and $52 \%$ respectively. Of the 1064 data points, $507(47.65 \%)$ are above 0.6 indicating moderately turbid conditions around Birtamode compared to highly turbid areas like New Delhi (76\%) (Tiwari et al., 2016) and Greater Noida (70\%) (Sharma et al., 2014). Nearly 18\% of the days exhibited very high AOD values (i.e., AOD $>$ mean $+1 \sigma$ ) and on these days $88 \%$ of $\alpha$ values are greater than 1 . This illustrates that the highly turbid conditions are due to the presence of finemode anthropogenic or biomass burning aerosols.

The AOD and $\alpha$ values from this work were compared with those over neighboring sites in the Indian subcontinent, and the results summarized in Table S1. The seasonal AOD values at Birtamode are comparable to those over Lumbini (Rupakheti et al., 2018) and Kanpur (Kaskaoutis et al., 2012). The AOD values are lower compared to highly polluted urban areas like Delhi (Tiwari et al., 2016), Bhubaneswar (Mukherjee and Vinoj, 2020), and Varanasi (Tiwari et al., 2018). However, Birtamode was seen to have higher AOD values compared to other locations in the Indian sub-continent (Alam et al., 2012; Gogoi et al., 2009). Thus, Birtamode can be considered a moderately polluted semi-urban environment. Similarly, $\alpha$ values during the post-monsoon and winter periods are lower compared to several locations in the IGP and surrounding areas including Varanasi, Lumbini, Kanpur, Karachi, and Greater Noida. This suggests the presence of coarser aerosols over the Birtamode area. 

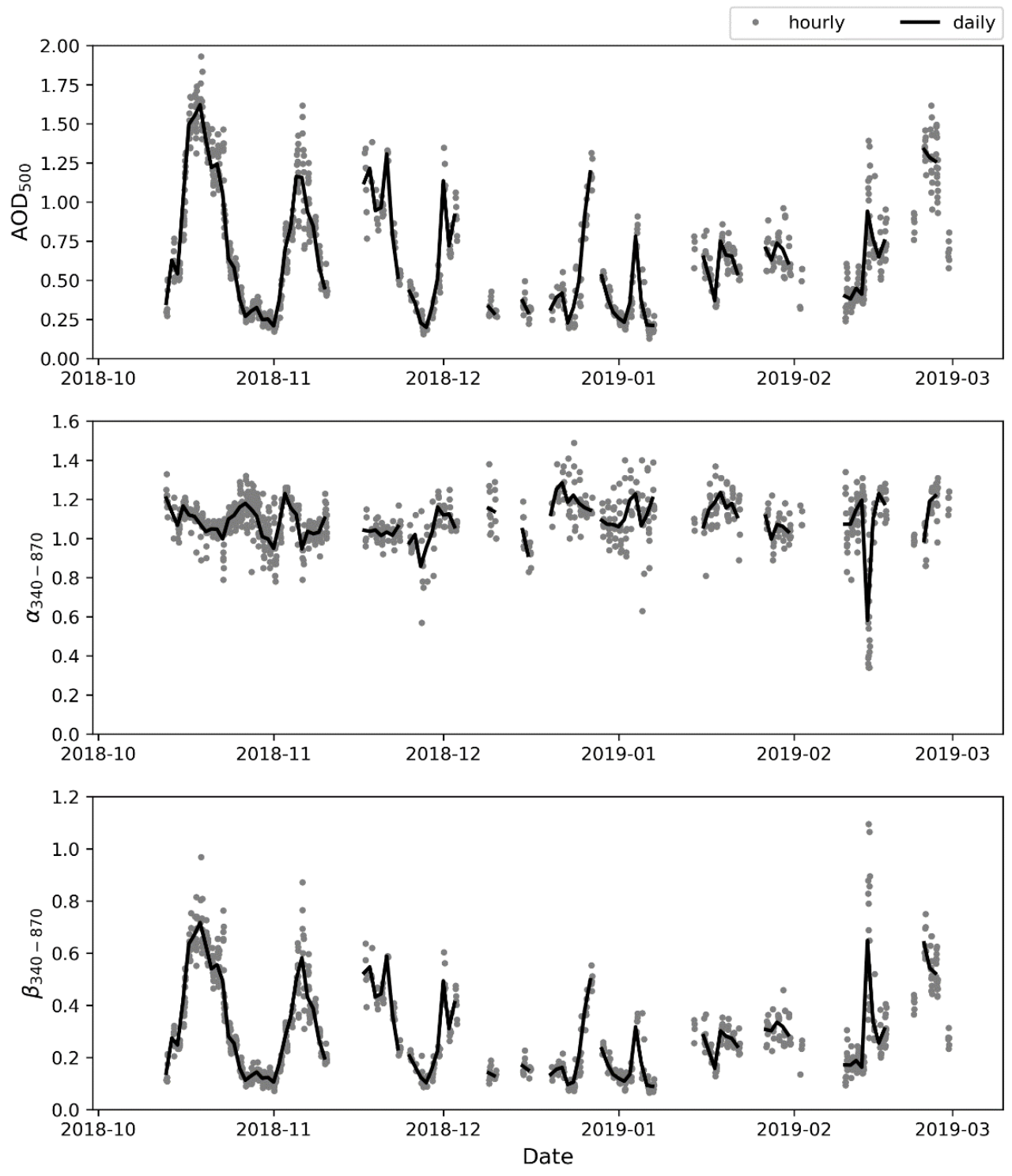

Fig. 2. Variation of Microtops AOD, $\alpha$, and $\beta$.

The monthly mean spectral variation of AOD (Fig. 3) shows significant differences between calendar months. Though the AODs at 870nm overall are quite similar ( 0.4), October and February exhibit slightly higher AODs $(\sim 1)$ at the shorter wavelength, which are due to the presence of fine-mode aerosols (Kedia and Ramachandran, 2011; Tiwari et al., 2018). However, no different spectral variation of monthly mean AODs is found between December and January, and October and February. The wavelength dependence of seasonal AOD over Birtamode is comparable to other sites where data is available in the IGP (Sharma et al., 2014; Tiwari et al., 2018).

The frequency distributions of AOD, $\alpha$, and $\beta$ reveal a wide range for both seasons (Fig. S2) which indicates the variability in aerosol types and size distribution. The higher AODs recorded $(>0.6)$ with nearly $50 \%$ and $40 \%$ contributions in the post-monsoon and winter seasons, indicate moderately turbid conditions in Birtamode. Moreover, $67 \%$ and $31 \%$ of the observed $\beta$ values greater than 0.2 and 0.4 respectively demonstrate that the post-monsoon period was more polluted compared to the winter period having $57 \%$ and $17 \%$ of $\beta$ values greater than 0.2 and 0.4 respectively (Iqbal, 1983; Sapkota and Dhaubhadel, 2002). However, Varanasi, a nearby IGP location had $76 \%$ and $64 \%$ of higher AODs $(>0.7$ ) in post-monsoon and winter respectively (Tiwari et al., 2018). The frequency distribution for AOD, $\alpha$, and $\beta$ values at Birtamode are unimodal during both seasons, with modal values close to $0.4,1.2$, and 0.2 respectively, which is attributed to the prevalence of certain aerosol types (Filonchyk et al., 2020). 


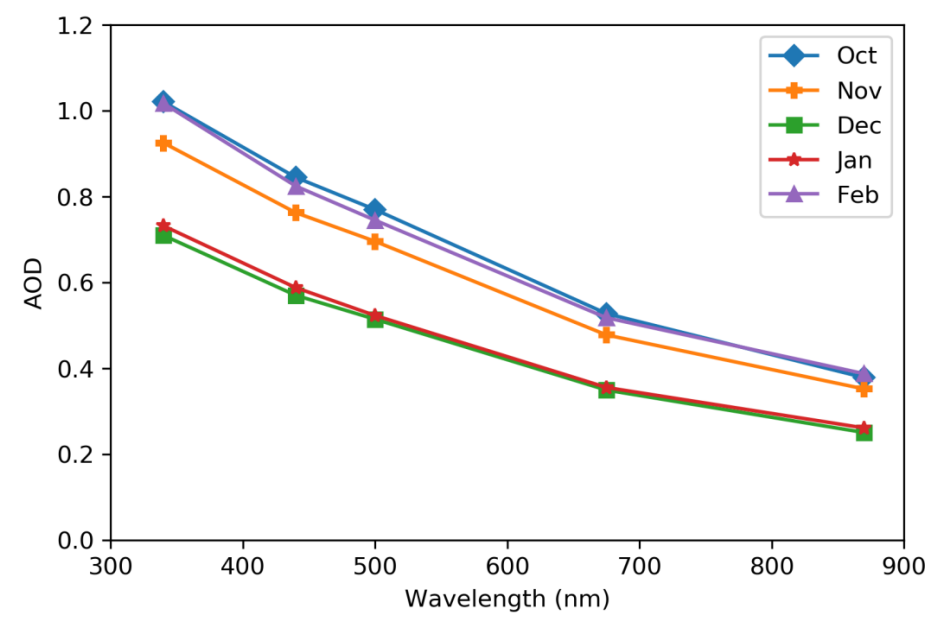

Fig. 3. Spectral variation of AOD (Oct-2018 to Feb-2019).

\subsection{Satellite and CAMS Retrieval Accuracy against Microtops Measurments}

Fig. 4 shows the comparison of satellite AOD retrievals and CAMS near-real-time analysis with ground-based observations over Birtamode. The total number of collocations with the ground observations were 66, 69, and 69 for Terra MODIS (10 km product) DB, DT, and combined DB-DT products. Similarly, for Aqua MODIS (10 km product) the collocations were 62, 60, and 60 respectively for DB, DT, and combined DB-DT products. For $3 \mathrm{~km}$ products, the valid collocations were 75 and 73 respectively for Terra and Aqua. Moreover, the numbers of matchups were 90, 872 , and 94 respectively for VIIRS, AHI, and CAMS. The relatively high number of collocations for $\mathrm{AHI}$ is due to its high temporal resolution of 10 minutes.

MODIS C6.1 aerosol products (both $10 \mathrm{~km}$ and $3 \mathrm{~km}$ ) have relative mean bias (RMB) values between 0.80 and 0.82 which suggests that they underestimate the AOD values by $18 \%-20 \%$. Terra MODIS AOD retrieved from the DB algorithm (MOD04_L2_DB) has the highest $\mathrm{R}^{2}$ of 0.945 . Compared to Aqua MODIS, Terra MODIS shows better agreement with the ground observation which is indicated by the higher $R^{2}$ value. The evaluation of these products over other areas in the Asian region show results with lower $\mathrm{R}^{2}$ values (Bilal et al., 2018; Huang et al., 2020; Sharma et al., 2021; Tian and Gao, 2019). This may be attributed to the lower number of data samples in the present study, and the difference in the spatial and temporal window size taken for collocation. The DT AOD and the merged DB-DT AOD show no difference for the Birtamode region. This is due to the merged product completely following the DT algorithm which indicates the region is moderately vegetated implied by the Normalized Difference Vegetation Index (NDVI) (Bilal et al., 2018). Similar observation of the DT AOD and DB-DT AOD have been reported with the C6 product for the Dhaka region (Mhawish et al., 2017).

VIIRS AOD has an RMB value of 0.89 and an $R^{2}$ of 0.856 which is lower when compared to the MODIS aerosol products. A global evaluation study from 23 January 2013 to 31 December 2014 showed that the AOD retrieval generally underestimated AOD over India during agricultural burning seasons. This study had 24145 analysis samples with an accuracy of -0.0008 , precision of 0.116 , uncertainty of 0.116 and correlation coefficient (R) of 0.817 (Huang et al., 2016).

The correlation between AHI AOD and ground observations has the lowest $R^{2}$ value (0.6) and an RMSE value of 0.32 . This overestimation may be attributed to the use of $L 2$ products which is likely to be affected by cloud contamination. However, both $L 3$ products, $A O D_{\text {pure }}$ and $A O D_{\text {merged, }}$ don't show much improvement in the correlation against ground observations (Fig. S3). The global validation of $L 3$ version 3 AOD shows that the $R^{2}$ values for different AERONET locations in nearby regions such as Bhola, Dhaka University, Pokhara, and Gandhi College are 0.66, 0.66, 0.77, and 0.38 respectively (Zhang et al., 2019). The underestimation of AOD by CAMS is comparable to that of MODIS. However, the $\mathrm{R}^{2}$ value is lower (0.713) and the RMSE (0.21) and MAE (0.16) values are higher than MODIS products. A previous study shows that CAMS reanalysis performs better when the climatology is dominated by coarse mode particles relative to fine mode particles. The performance of CAMS near real-time data with the ground observation over the Birtamode 

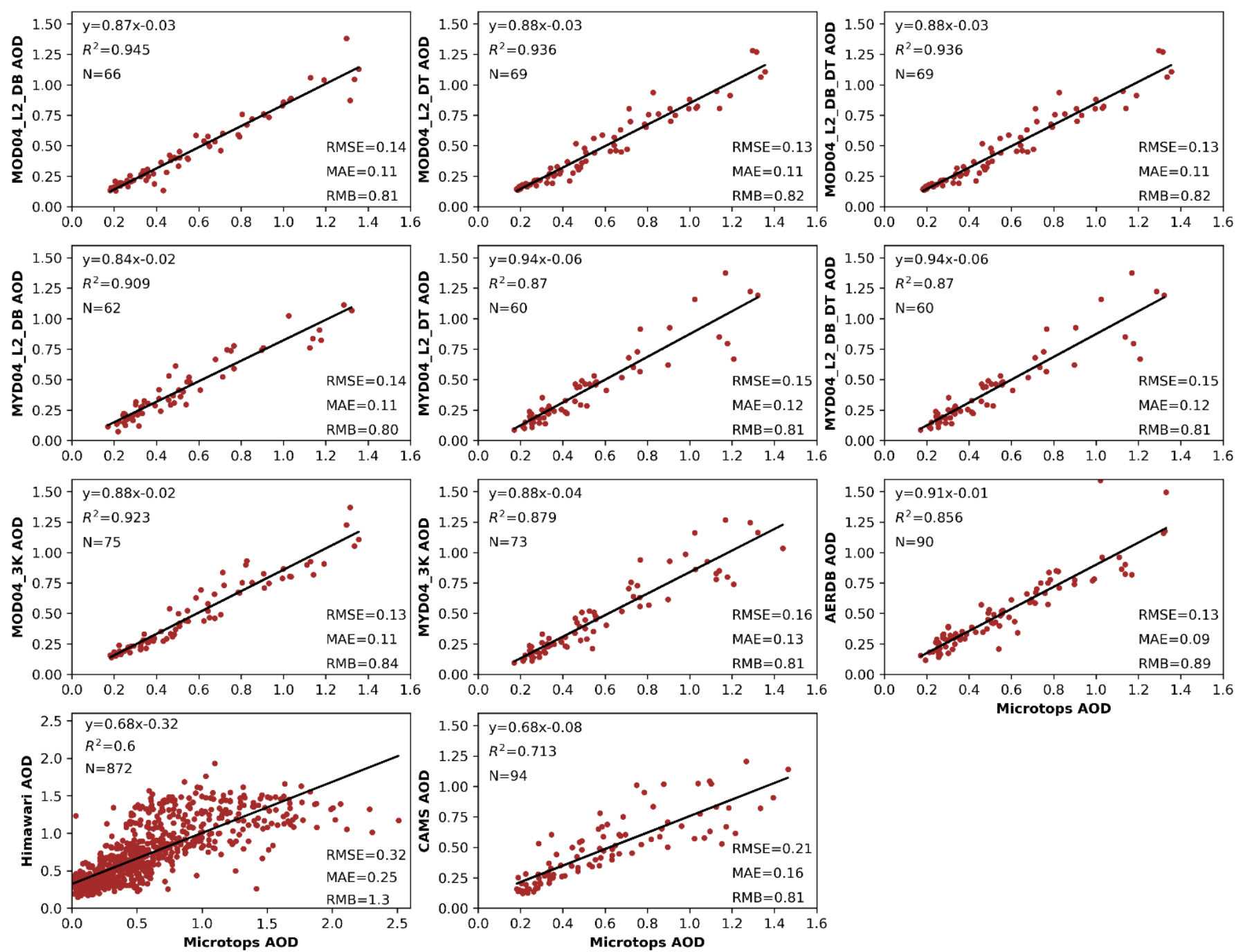

Fig. 4. Evaluation of various satellite and model-based aerosols products with ground-based observation obtained from Microtops.

region is better compared to other locations in the IGP such as Kanpur, Lahore, Gandhi College, and Jaipur where the reanalysis product was evaluated (Misra et al., 2020).

\subsection{Spatial Distribution of Satellite and CAMS AOD}

Fig. 5 shows the spatial distribution of MODIS, VIIRS, AHI, and CAMS AOD over the eastern Himalaya foothills region for the post-monsoon and winter seasons. Although plume features are captured by various platforms, there are significant differences between them. The aerosol loads obtained from all platforms show higher AOD around the central IGP and the Bay of Bengal than the northeast areas including the Birtamode region. This is possibly due to anthropogenic activity including industrial activity in those regions. The evaluation results in the previous section show that the Terra MODIS (10 km product) has a higher accuracy than other products when compared to ground-based observation. So, the spatial distribution of VIIRS, AHI, and CAMS AOD were evaluated based on MODIS AOD retrievals. The percentage AOD difference in Fig. 6 is defined as "100 $\times($ Other - MODIS)/MODIS", which describes the average difference between MODIS and other products. For consistency, the resolution of MODIS and the other products were kept constant by regriding to calculate the difference. During the post-monsoon, similar aerosol load distributions are found in MODIS and VIIRS plots over the IGP, although VIIRS tends to overestimate the value along the Brahmaputra and the Ganges rivers and underestimates the value along the eastern Himalaya. However, during winter, VIIRS overestimates the AOD value over eastern India Himalaya 

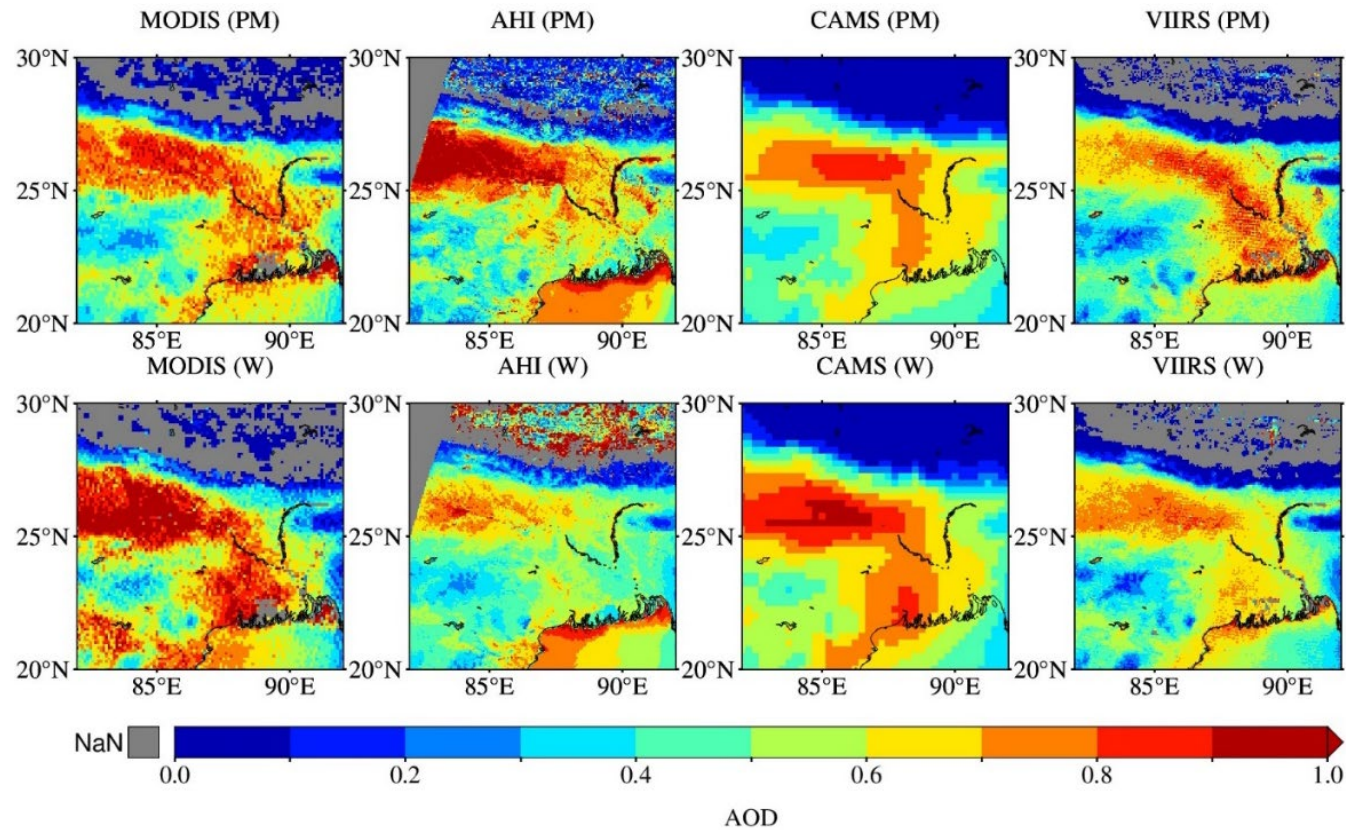

Fig. 5. Spatial distribution of satellite and model AOD during post-monsoon (PM) and winter (W) seasons.

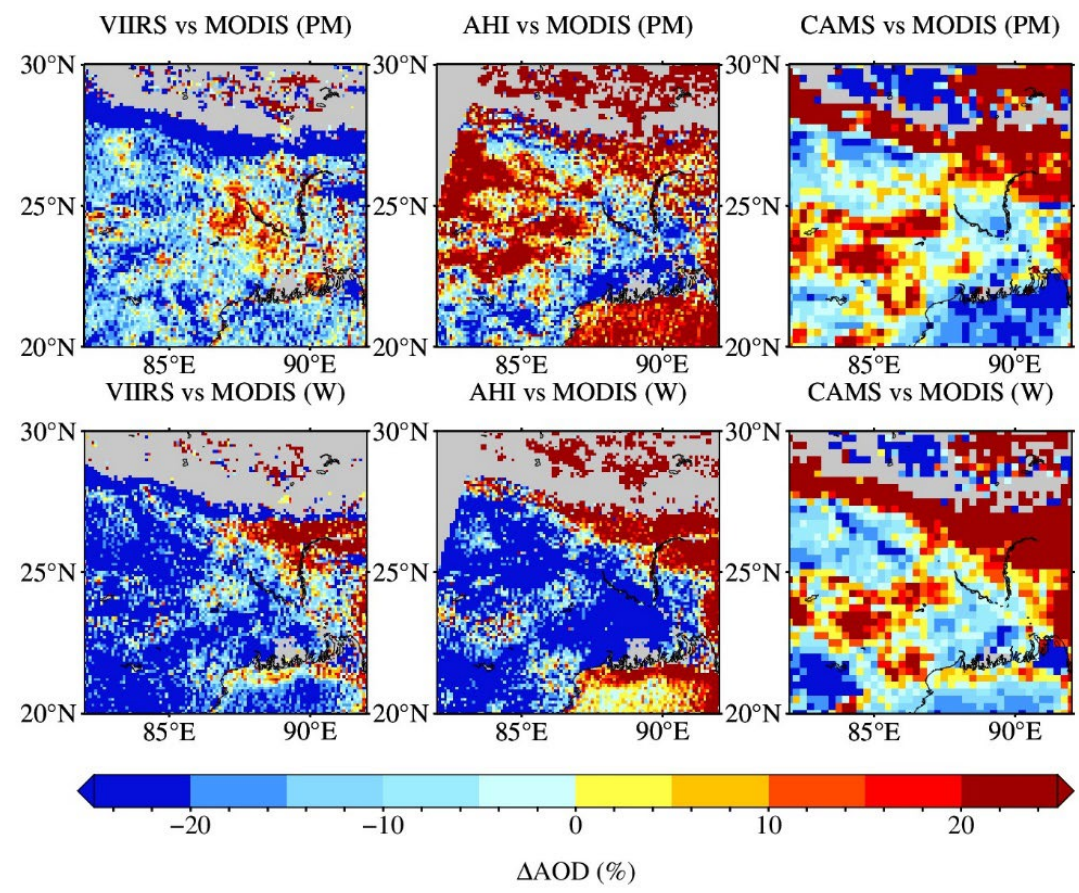

Fig. 6. Spatial distribution of the AOD difference during post-monsoon (PM) and winter (W).

and mostly underestimates values over the IGP. When AOD from AHI and MODIS are compared, the IGP region shows strong sensitivity to seasonal change; $A H I A O D$ is significantly higher while the same region shows significantly lower MODIS AOD. AHI continues to overestimate along the foothills and the southern face of the eastern Himalayas and the Bay of Bengal. CAMS overestimates the AOD values over parts of the IGP and along the eastern Himalaya foothills while it underestimates the value over the Bay of Bengal during both seasons. The evaluation of AHI L3 data suggests that the $A O D_{\text {pure }}$ and $A O D_{\text {merged }}$ products show improvement over both land and ocean which is demonstrated by lower overestimation as compared to AHI L2 data (Fig. S4). 


\subsection{Classification of Aerosols}

Correlating AOD and $\alpha$ is one method for classifying aerosols (Kaskaoutis et al., 2009). To classify different aerosol types in Birtamode, scatter plots (Fig. 7) between AOD and $\alpha$ are used. This study used a similar threshold to those used in Varanasi (Tiwari et al., 2018) as AOD >0.7 and $\alpha<0.6$ (Mostly dust; MD); $0.3 \leq \mathrm{AOD} \leq 1$ and $\alpha>0.9$ (Anthropogenic aerosol; AA); AOD > 1.0 and $\alpha>1.0$ (Biomass burning; BB) and those used in New Delhi (Sharma et al., 2014) as AOD $<0.3$ and $\alpha<0.9$ (CBC). The cases that don't belong to these categories are categorized as mixed type (MT) aerosols.

During the post-monsoon season, the contribution of AA type aerosol is the highest ( $54 \%)$ which is followed by BB type aerosol ( 22\%). Similarly, AA and BB types during winter have contributions of $66 \%$ and $11 \%$ respectively. The high frequency of BB type aerosol during the post-monsoon may be attributed to extensive agricultural residue burning in the IGP (Rupakheti et al., 2018). The CBC type has negligible contribution during both seasons. Similarly, a negligible contribution of $\mathrm{MD}(2.41 \%)$ is seen during winter which is attributed to the strong surface winds carrying dust from several construction sites in the vicinity.

Fig. 8 shows the spatial distribution of CAMS aerosol types in the study domain. The organic matter AOD seems to have a major contribution ( $~ 50 \%$ each in post-monsoon and winter) of the total AOD, which is followed by sulfate $A O D$ ( $38 \%$ and $40 \%$ in post-monsoon and winter respectively). The contribution of dust AOD and black carbon AOD is equal in post-monsoon ( 5\%) which is double i.e., $\sim 3 \%$ by dust and $\sim 6 \%$ by $B C$ during winter. However, the contribution of sea-salt AOD is negligible during both post-monsoon and winter seasons. Though the temporal contribution of different aerosols varies, the hotspots of the black carbon, organic matter and sulfate remain the same as shown by the model output. A study over Kolkata, a neighboring megacity, with MERRA-2 reanalysis data showed that the seasonal average of sulfate AOD from 2001-2017 for both postmonsoon and winter is the highest followed by organic carbon, black carbon, and dust (Rawat et al., 2019). Given the higher emissions of $\mathrm{SO}_{2}$ from fossil fuel burning in the megacity versus rural

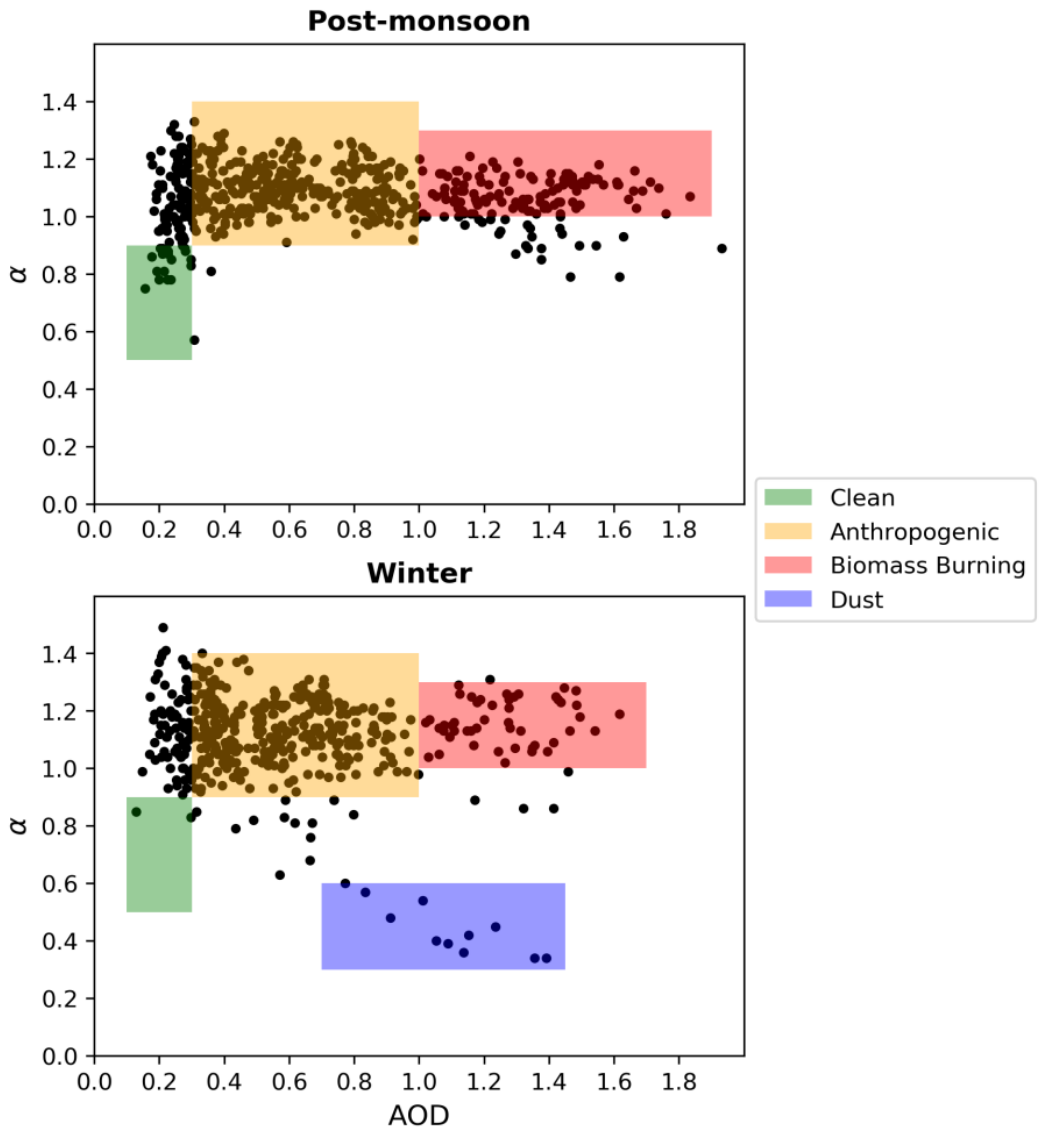

Fig. 7. Scatter plot between AOD and $\alpha$. 

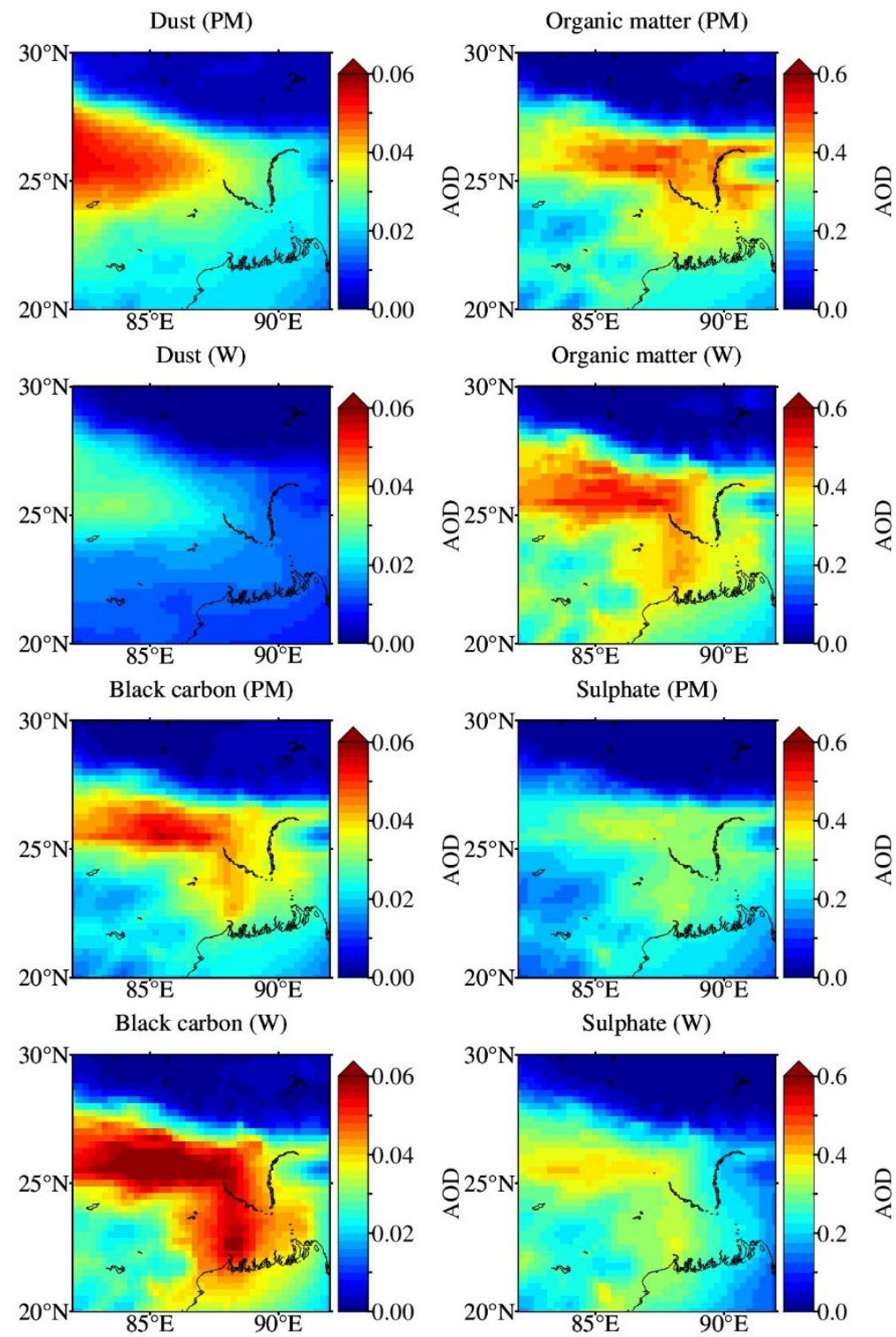

Fig. 8. Spatial distribution of CAMS aerosol type during post-monsoon (PM) and winter (W).

area, it is expected that sulfate would dominate the AOD over Kolkata versus our study domain that includes two megacities (Kolkata and Delhi) but is dominated by carbonaceous aerosols emitted from the surrounding rural environment.

\subsection{Vertical Variation of Aerosol}

The CALIPSO profiles for post-monsoon and winter seasons (Fig. 9) show the vertical distribution of aerosol within the domain where the plume from the IGP and the Bay of Bengal converge. Majority of aerosols are confined to altitude below $2 \mathrm{~km}$ during post-monsoon while there seems to be a slightly elevated layer with $b_{\text {ext }}>0.1 \mathrm{~km}^{-1}$ around $3 \mathrm{~km}$. However, during winter, several elevated layers are present with $b_{\text {ext }}>0.2 \mathrm{~km}^{-1}$ above $2 \mathrm{~km}$ altitude. The CALIPSO profiles obtained for our study domain have been compared with other studies in the nearby locations. Unlike the present study, the vertical profile for the winter season in the central IGP doesn't show prominent features (Mahapatra et al., 2019). However, the study over Delhi NCR region shows that the daytime mean seasonal bext for the winter season has a secondary peak at an altitude of around $2.6 \mathrm{~km}$ which is comparable to this study with one of the secondary peaks lying at $3 \mathrm{~km}$. During post-monsoon season, bext has a secondary peak at a relatively lower altitude $(0.8 \mathrm{~km})$ over Delhi NCR compared to the present study domain (Srivastava et al., 2014). Both 

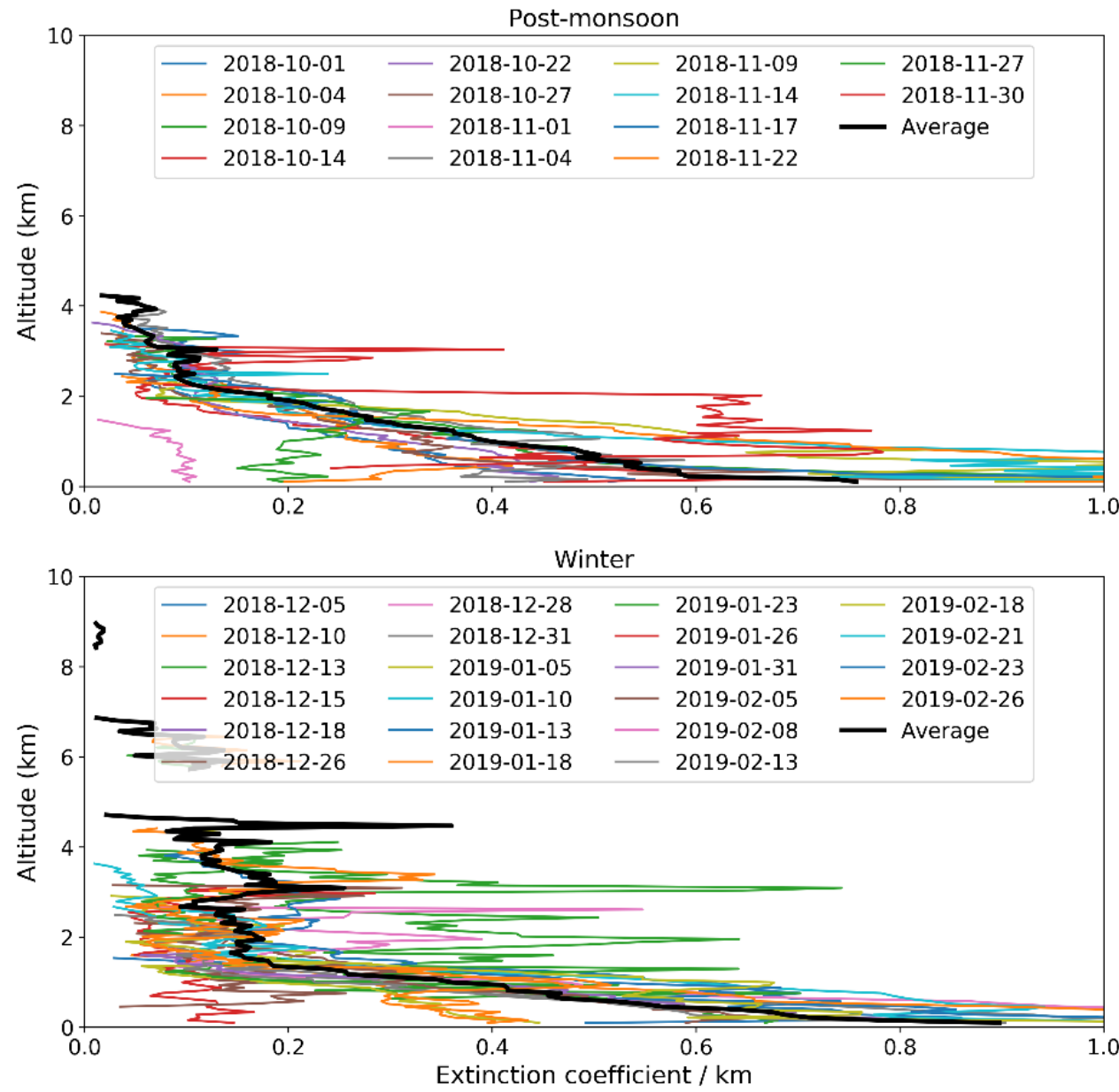

Fig. 9. Averaged CALIPSO extinction coefficient over the eastern Himalaya foothills region.

studies do show a lowered elevated aerosol layer (implied via bext peak) during the post-monsoon season compared to the winter season. Climatological analysis of the planetary boundary layer (PBL) implies that PBL is lower over the IGP and the surroundings during the winter versus the post-monsoon season which should lead to higher elevated aerosol layers during the postmonsoon versus winter season (Putero et al., 2018; Raatikainen et al., 2014). The reason for the lowered elevated aerosol layer during the post-monsoon season versus winter needs further research. The Micropulse Lidar Network (MPLNET) - derived extinction coefficients over Kanpur (central IGP) during post- monsoon seasons show high values near the surface with no secondary peak value (Misra et al., 2012). For post-monsoon season, Dhaka, Agratala, Guwahati, Banmauk, Dhubri, Imphal, Aizawi, Shillong, Tawang, and Thimphu have high values of bext near the surface with secondary peaks at an altitude between $2.5-3 \mathrm{~km}$ similar to our findings. Whereas, Dibrugarh a city in the eastern Himalaya region has an elevated peak layer at $1 \mathrm{~km}$ altitude (Dahutia et al., 2019). The results indicate that even within the IGP there is a great seasonal variation, as well as the height of the elevated aerosol layers. The difference in the magnitude of bext values and the vertical profile for different locations may also be attributed to the different methodological approaches of using the CALIPSO dataset and the duration of studies.

Fig. 10 shows the CAMS model derived vertical concentration profiles of organic matter, black carbon, and sulfate aerosols over the eastern Himalaya foothills region similar to that of CALIPSO analysis. Unlike CALIPSO observations, the model shows all these aerosols declining with altitude. Given the coarseness of the model vertical layers, it is expected that the model will not be able to resolve the layers obtained from the CALIPSO profiles. Model-based results do not show much difference in the vertical profiles of all three aerosol types between post-monsoon and winter season. 


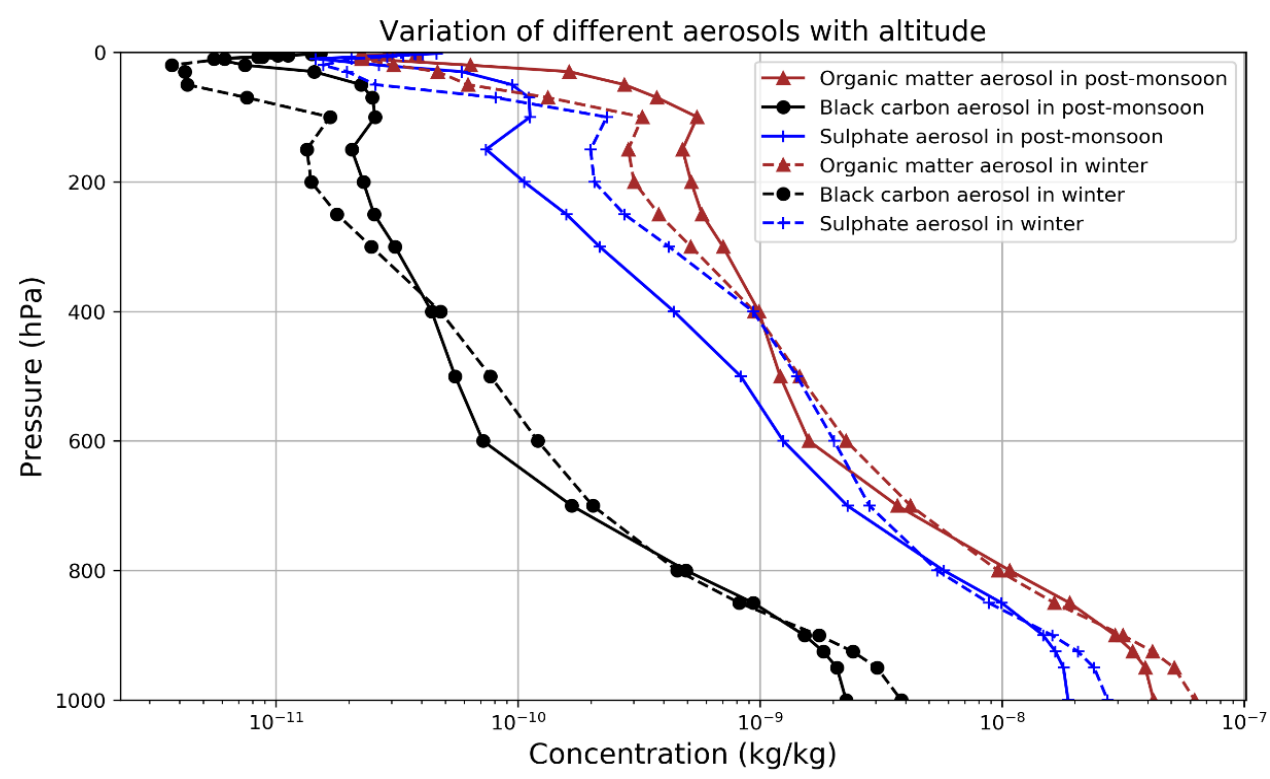

Fig. 10. Vertical profiles of aerosol mass concentration predicted by CAMS model.

\section{CONCLUSIONS}

The satellite-based observations of AOD show the hotspots over the eastern Himalayan foothills region. This study provides a comprehensive analysis of the ground-based AOD and various satellite-based and modeled aerosol products. A comparison of seasonal aerosol optical depth values over Birtamode, study site, with previous studies in the vicinity shows that the atmospheric condition of Birtamode is comparable to that of Lumbini and Kanpur. The AOD values are lower than the observed values at the highly polluted stations (Delhi and Varanasi) of the IGP region. The frequency distribution of AOD indicates that Birtamode is moderately polluted compared to other locations in IGP. However, the AOD and $\alpha$ values being higher compared with other cities in the Indian subcontinent, Birtamode may be considered as a polluted and aerosol-laden semi-urban area. The seasonal-average value of $\beta$ signifies higher aerosol loading over the eastern Himalayan foothills region during the post-monsoon season, contrary to the observations recorded in the central Himalaya foothills region. Aerosols are classified based on the correlation of AOD and $\alpha$, which shows that the contribution of anthropogenic aerosol type is the highest among all others. However, biomass burning contributions to the total aerosol loading are higher during the post-monsoon season. The evaluation of MODIS, VIIRS, AHI, and CAMS aerosol products was carried out for the first time in the eastern Himalaya region with Microtops ground observations. The MODIS AOD values from both Terra and Aqua satellites show a good correlation with groundbased observations compared to other platforms and provide the opportunity for further research based on MODIS values. Besides, evaluations of various MODIS AOD products such as DB, DT, and combined DB-DT have also been conducted. The DB product shows a better correlation for Birtamode despite the number of collocation points being slightly lower than DT and merged DBDT products. The values obtained from the combined DB-DT algorithm didn't show differences from the values obtained from the DT algorithm, which is mainly due to the DT contribution in aerosol retrieval. AHI AOD ( $\mathrm{R}^{2}$ of 0.6 ) seems promising with a higher frequency of AOD points to monitor intra-day variation. The comparison of the spatial distribution of AOD shows that AHI and CAMS overestimate the value over the eastern Himalaya foothills, whereas VIIRS overestimates the value only during the winter season. The CAMS aerosol products were used to identify aerosol composition and vertical profiles over the eastern Himalaya foothills region. The model, as anticipated, was unable to capture the fine vertical aloft layers, unlike CALIPSO observations. CALIPSO vertical profiles show similar results as in north-eastern India, with the majority of the pollutants confined within $3 \mathrm{~km}$ of the boundary layer. However, the lowered elevated aerosol layer during the post-monsoon season versus the winter season requires further research. 


\section{ACKNOWLEDGEMENTS}

This study was partially supported by core funds of ICIMOD contributed by the governments of Afghanistan, Australia, Austria, Bangladesh, Bhutan, China, India, Myanmar, Nepal, Norway, Pakistan, Sweden, Switzerland, and the United Kingdom. The views and interpretations in this publication are those of the authors and are not necessarily attributable to their associated institutions. The authors acknowledge Dr. Mohammad Iqbal Mead from ICIMOD for the valuable comments. Sishir Dahal acknowledges the Department of Applied Sciences and Chemical Engineering, Pulchowk Campus, Institute of Engineering, Tribhuvan University for providing Microtops II sunphotometer used in this study and Asst. Prof. Jayandra Kumar Shrestha and Assoc. Prof. Manoj Kumar Thapa for providing valuable insights during the study period. The authors are thankful to the editor and the anonymous reviewers for their comments and suggestions, which enriched the quality of this manuscript.

\section{DISCLAIMER}

The authors declare that they have no actual or potential competing financial benefits.

\section{SUPPLEMENTARY MATERIAL}

Supplementary material for this article can be found in the online version at https://doi. org/10.4209/aaqr.210152

\section{REFERENCES}

Adhikary, B., Carmichael, G.R., Tang, Y., Leung, L.R., Qian, Y., Schauer, J.J., Stone, E.A., Ramanathan, V., Ramana, M. V. (2007). Characterization of the seasonal cycle of south Asian aerosols: A regional-scale modeling analysis. J. Geophys. Res. 112, D22S22. https://doi.org/ 10.1029/2006JD008143

Alam, K., Trautmann, T., Blaschke, T., Majid, H. (2012). Aerosol optical and radiative properties during summer and winter seasons over Lahore and Karachi. Atmos. Environ. 50, 234-245. https://doi.org/10.1016/j.atmosenv.2011.12.027

Ångström, A. (1964). The parameters of atmospheric turbidity. Tellus 16, 64-75. https://doi.org/ 10.1111/j.2153-3490.1964.tb00144.x

Bibi, H., Alam, K., Chishtie, F., Bibi, S., Shahid, I., Blaschke, T. (2015). Intercomparison of MODIS MISR, OMI, and CALIPSO aerosol optical depth retrievals for four locations on the IndoGangetic plains and validation against AERONET data. Atmos. Environ. 111, 113-126. https://doi.org/10.1016/j.atmosenv.2015.04.013

Bilal, M., Nazeer, M., Qiu, Z., Ding, X., Wei, J. (2018). Global validation of MODIS C6 and C6.1 merged aerosol products over diverse vegetated surfaces. Remote Sens. 10, 475. https://doi.org/10.3390/rs10030475

Cho, C., Kim, S.W., Rupakheti, M., Park, J.-S., Panday, A., Yoon, S.C., Kim, J.H., Kim, H., Jeon, H., Sung, M., Kim, B.M., Hong, S.K., Park, R.J., Rupakheti, D., Mahata, K.S., Praveen, P.S., Lawrence, M.G., Holben, B. (2017). Wintertime aerosol optical and radiative properties in the Kathmandu Valley during the SusKat-ABC field campaign. Atmos. Chem. Phys. 17, 12617-12632 https://doi.org/10.5194/acp-17-12617-2017

Dahutia, P., Pathak, B., Bhuyan, P.K. (2019). Vertical distribution of aerosols and clouds over north-eastern South Asia: Aerosol-cloud interactions. Atmos. Environ. 215, 116882. https://doi.org/10.1016/j.atmosenv.2019.116882

Filonchyk, M., Hurynovich, V., Yan, H. (2020). Trends in aerosol optical properties over Eastern Europe based on MODIS-Aqua. Geosci. Front. 11, 2169-2181. https://doi.org/10.1016/ j.gsf.2020.03.014

Fukuda, S., Nakajima, T., Takenaka, H., Higurashi, A., Kikuchi, N., Nakajima, T.Y., Ishida, H. (2013). New approaches to removing cloud shadows and evaluating the $380 \mathrm{~nm}$ surface reflectance 
for improved aerosol optical thickness retrievals from the GOSAT/TANSO-Cloud and Aerosol Imager. J. Geophys. Res. 118, 13520-13531. https://doi.org/10.1002/2013JD020090

Ganguly, D., Jayaraman, A., Gadhavi, H. (2006). Physical and optical properties of aerosols over an urban location in western India: Seasonal variabilities. J. Geophys. Res. 111, D24206. https://doi.org/10.1029/2006JD007392

Gautam, R., Hsu, N.C., Tsay, S.C., Lau, K.M., Holben, B., Bell, S., Smirnov, A., Li, C., Hansell, R., Ji, Q., Payra, S., Aryal, D., Kayastha, R., Kim, K.M. (2011). Accumulation of aerosols over the IndoGangetic plains and southern slopes of the Himalayas: Distribution, properties and radiative effects during the 2009 pre-monsoon season. Atmos. Chem. Phys. 11, 12841-12863. https://doi.org/10.5194/acp-11-12841-2011

Gogoi, M.M., Krishna Moorthy, K., Babu, S.S., Bhuyan, P.K. (2009). Climatology of columnar aerosol properties and the influence of synoptic conditions: First-time results from the northeastern region of India. J. Geophys. Res. 114, D08202. https://doi.org/10.1029/ 2008JD010765

Gupta, P., Levy, R.C., Mattoo, S., Remer, L.A., Munchak, L.A. (2016). A surface reflectance scheme for retrieving aerosol optical depth over urban surfaces in MODIS Dark Target retrieval algorithm. Atmos. Meas. Tech. 9, 3293-3308. https://doi.org/10.5194/amt-9-3293-2016

Hegg, D.A., Hobbs, P. V., Gassó, S., Nance, J.D., Rangno, A.L. (1996). Aerosol measurements in the Arctic relevant to direct and indirect radiative forcing. J. Geophys. Res. 101, 23349-23363. https://doi.org/10.1029/96JD02246

Hsu, N.C., Jeong, M.J., Bettenhausen, C., Sayer, A.M., Hansell, R., Seftor, C.S., Huang, J., Tsay, S.C. (2013). Enhanced deep blue aerosol retrieval algorithm: The second generation. J. Geophys. Res. 118, 9296-9315. https://doi.org/10.1002/jgrd.50712

Huang, G., Chen, Y., Li, Z., Liu, Q., Wang, Y., He, Q., Liu, T., Liu, X., Zhang, Y., Gao, J., Yao, Y. (2020). Validation and accuracy analysis of the collection 6.1 MODIS aerosol optical depth over the westernmost city in China based on the sun-sky radiometer observations from SONET. Earth Sp. Sci. 7, e2019EA001041. https://doi.org/10.1029/2019EA001041

Huang, J., Kondragunta, S., Laszlo, I., Liu, H., Remer, L.A., Zhang, H., Superczynski, S., Ciren, P., Holben, B.N., Petrenko, M. (2016). Validation and expected error estimation of Suomi-NPP VIIRS aerosol optical thickness and Ångström exponent with AERONET. J. Geophys. Res. 121, 7139-7160. https://doi.org/10.1002/2016JD024834

Ichoku, C. (2002a). Analysis of the performance characteristics of the five-channel Microtops II Sun photometer for measuring aerosol optical thickness and precipitable water vapor. J. Geophys. Res. 107, 4179. https://doi.org/10.1029/2001JD001302

Ichoku, C. (2002b). A spatio-temporal approach for global validation and analysis of MODIS aerosol products. Geophys. Res. Lett. 29, 8006. https://doi.org/10.1029/2001GL013206

Iqbal, M. (1983). An Introduction to Solar Radiation, An Introduction to Solar Radiation. Elsevier. https://doi.org/10.1016/B978-0-12-373750-2.X5001-0

Jackson, J.M., Liu, H., Laszlo, I., Kondragunta, S., Remer, L.A., Huang, J., Huang, H.C. (2013). SuomiNPP VIIRS aerosol algorithms and data products. J. Geophys. Res. 118, 12,673-12,689. https://doi.org/10.1002/2013JD020449

Jethva, H., Torres, O., Yoshida, Y. (2019). Accuracy assessment of MODIS land aerosol optical thickness algorithms using AERONET measurements over North America. Atmos. Meas. Tech. 12, 4291-4307. https://doi.org/10.5194/amt-12-4291-2019

Kaskaoutis, D.G., Badarinath, K.V.S., Kumar Kharol, S., Rani Sharma, A., Kambezidis, H.D. (2009). Variations in the aerosol optical properties and types over the tropical urban site of Hyderabad, India. J. Geophys. Res. 114, D22204. https://doi.org/10.1029/2009JD012423

Kaskaoutis, D.G., Singh, R.P., Gautam, R., Sharma, M., Kosmopoulos, P.G., Tripathi, S.N. (2012). Variability and trends of aerosol properties over Kanpur, northern India using AERONET data (2001-10). Environ. Res. Lett. 7, 024003. https://doi.org/10.1088/1748-9326/7/2/024003

Kaufman, Y.J., Fraser, R.S. (1983). Light extinction by aerosols during summer air pollution. J. Clim. Appl. Meteorol. 22, 1694-1706. https://doi.org/10.1175/1520-0450(1983)022<1694:LEBADS $>2.0 . \mathrm{CO} ; 2$

Kaufman, Y.J., Tanré, D., Boucher, O. (2002). A satellite view of aerosols in the climate system. Nature 419, 215-223. https://doi.org/10.1038/nature01091

Kedia, S., Ramachandran, S. (2011). Seasonal variations in aerosol characteristics over an urban 
location and a remote site in western India. Atmos. Environ. 45, 2120-2128. https://doi.org/ 10.1016/j.atmosenv.2011.01.040

Kikuchi, M., Murakami, H., Suzuki, K., Nagao, T.M., Higurashi, A. (2018). Improved hourly estimates of aerosol optical thickness using spatiotemporal variability derived From Himawari-8 geostationary satellite. IEEE Trans. Geosci. Remote Sens. 56, 3442-3455. https://doi.org/ 10.1109/TGRS.2018.2800060

Lau, K.M., Kim, M.K., Kim, K.M. (2006). Asian summer monsoon anomalies induced by aerosol direct forcing: The role of the Tibetan Plateau. Clim. Dyn. 26, 855-864. https://doi.org/ 10.1007/s00382-006-0114-z

Levy, R.C., Remer, L.A., Mattoo, S., Vermote, E.F., Kaufman, Y.J. (2007). Second-generation operational algorithm: Retrieval of aerosol properties over land from inversion of Moderate Resolution Imaging Spectroradiometer spectral reflectance. J. Geophys. Res. 112, 2006JD007811. https://doi.org/10.1029/2006JD007811

Lohmann, U., Feichter, J. (2005). Global indirect aerosol effects: A review. Atmos. Chem. Phys. 5, 715-737. https://doi.org/10.5194/acp-5-715-2005

Mahapatra, P.S., Puppala, S.P., Adhikary, B., Shrestha, K.L., Dawadi, D.P., Paudel, S.P., Panday, A.K. (2019). Air quality trends of the Kathmandu Valley: A satellite, observation and modeling perspective. Atmos. Environ. 201, 334-347. https://doi.org/10.1016/j.atmosenv.2018.12.043

Meehl, G.A., Arblaster, J.M., Collins, W.D. (2008). Effects of black carbon aerosols on the Indian monsoon. J. Clim. 21, 2869-2882. https://doi.org/10.1175/2007JCLI1777.1

Mhawish, A., Banerjee, T., Broday, D.M., Misra, A., Tripathi, S.N. (2017). Evaluation of MODIS Collection 6 aerosol retrieval algorithms over Indo-Gangetic Plain: Implications of aerosols types and mass loading. Remote Sens. Environ. 201, 297-313. https://doi.org/10.1016/j.rse. 2017.09.016

Misra, A., Tripathi, S.N., Kaul, D.S., Welton, E.J. (2012). Study of MPLNET-derived aerosol climatology over Kanpur, India, and validation of CALIPSO Level 2 Version 3 backscatter and extinction products. J. Atmos. Ocean. Technol. 29, 1285-1294. https://doi.org/10.1175/JTECHD-11-00162.1

Misra, A., Tripathi, S., Sembhi, H., Boesch, H. (2020). Validation of CAMS AOD using AERONET data and trend analysis at four locations in the Indo-Gangetic Basin. Ann. Geophys. Discuss. [preprint], https://doi.org/10.5194/angeo-2020-40

Morcrette, J.J., Boucher, O., Jones, L., Salmond, D., Bechtold, P., Beljaars, A., Benedetti, A., Bonet, A., Kaiser, J.W., Razinger, M., Schulz, M., Serrar, S., Simmons, A.J., Sofiev, M., Suttie, M., Tompkins, A.M., Untch, A. (2009). Aerosol analysis and forecast in the European Centre for Medium-Range Weather Forecasts Integrated Forecast System: Forward modeling. J. Geophys. Res. 114, D06206. https://doi.org/10.1029/2008JD011235

More, S., Kumar, P.P., Gupta, P., Devara, P.C.S., Aher, G.R. (2013). Comparison of aerosol products retrieved from AERONET, MICROTOPS and MODIS over a tropical urban city, Pune, India. Aerosol Air Qual. Res. 13, 107-121. https://doi.org/10.4209/aaqr.2012.04.0102

Morys, M., Mims, F.M., Hagerup, S., Anderson, S.E., Baker, A., Kia, J., Walkup, T. (2001). Design, calibration, and performance of MICROTOPS II handheld ozone monitor and Sun photometer. J. Geophys. Res. 106, 14573-14582. https://doi.org/10.1029/2001JD900103

Mukherjee, T., Vinoj, V. (2020). Atmospheric aerosol optical depth and its variability over an urban location in Eastern India. Nat. Hazards 102, 591-605. https://doi.org/10.1007/s11069019-03636-x

Pathak, B., Bhuyan, P.K., Gogoi, M., Bhuyan, K. (2012). Seasonal heterogeneity in aerosol types over Dibrugarh-North-Eastern India. Atmos. Environ. 47, 307-315. https://doi.org/10.1016/ j.atmosenv.2011.10.061

Pawar, G.V., Devara, P.C.., More, S.D., Kumar, P.P., Aher, G.R. (2012). Determination of aerosol characteristics and direct radiative forcing at Pune. Aerosol Air Qual. Res. 12, 1166-1180. https://doi.org/10.4209/aaqr.2011.09.0157

Penner, J.E., Zhang, S.Y., Chuang, C.C. (2003). Soot and smoke aerosol may not warm climate. J. Geophys. Res. 108, 4657. https://doi.org/10.1029/2003JD003409

Putero, D., Marinoni, A., Calzolari, F., Rupakheti, M., Cristofanelli, P., Bonasoni, P. (2018). Black carbon and ozone variability at the kathmandu valley and at the southern Himalayas: A comparison between a "hot spot" and a downwind high-altitude site. Aerosol Air Qual. Res. 
18, 623-635. https://doi.org/10.4209/aaqr.2017.04.0138

Raatikainen, T., Hyvärinen, A.-P., Hatakka, J., Panwar, T.S., Hooda, R.K., Sharma, V.P., Lihavainen, $H$. (2014). The effect of boundary layer dynamics on aerosol properties at the Indo-Gangetic plains and at the foothills of the Himalayas. Atmos. Environ. 89, 548-555. https://doi.org/ 10.1016/j.atmosenv.2014.02.058

Ramachandran, S., Srivastava, R., Kedia, S., Rajesh, T.A. (2012). Contribution of natural and anthropogenic aerosols to optical properties and radiative effects over an urban location. Environ. Res. Lett. 7, 034028. https://doi.org/10.1088/1748-9326/7/3/034028

Ramachandran, S., Rupakheti, M. (2021). Inter-annual and seasonal variations in optical and physical characteristics of columnar aerosols over the Pokhara Valley in the Himalayan foothills. Atmos. Res. 248, 105254. https://doi.org/10.1016/j.atmosres.2020.105254

Rawat, P., Sarkar, S., Jia, S., Khillare, P.S., Sharma, B. (2019). Regional sulfate drives long-term rise in AOD over megacity Kolkata, India. Atmos. Environ. 209, 167-181. https://doi.org/10.1016/ j.atmosenv.2019.04.031

Regmi, J., Poudyal, K.N., Pokhrel, A., Gyawali, M., Tripathee, L., Panday, A., Barinelli, A., Aryal, R. (2020). Investigation of aerosol climatology and long-range transport of aerosols over Pokhara, Nepal. Atmosphere 11, 874. https://doi.org/10.3390/atmos11080874

Remer, L.A., Mattoo, S., Levy, R.C., Munchak, L.A. (2013). MODIS 3 km aerosol product: Algorithm and global perspective. Atmos. Meas. Tech. 6, 1829-1844. https://doi.org/10.5194/amt-61829-2013

Rimal, B., Zhang, L., Keshtkar, H., Wang, N., Lin, Y. (2017). Monitoring and modeling of spatiotemporal urban expansion and land-use/land-cover change using integrated Markov chain cellular automata model. ISPRS Int. J. Geo-Inf. 6, 288. https://doi.org/10.3390/ijgi60 90288

Rupakheti, D., Kang, S., Rupakheti, M., Cong, Z., Panday, A.K., Holben, B.N. (2019). Identification of absorbing aerosol types at a site in the northern edge of Indo-Gangetic Plain and a polluted valley in the foothills of the central Himalayas. Atmos. Res. 223, 15-23. https://doi.org/ 10.1016/j.atmosres.2019.03.003

Rupakheti, D., Kang, S., Rupakheti, M., Cong, Z., Tripathee, L., Panday, A.K., Holben, B.N. (2018). Observation of optical properties and sources of aerosols at Buddha's birthplace, Lumbini, Nepal: environmental implications. Environ. Sci. Pollut. Res. 25, 14868-14881. https://doi.org/ 10.1007/s11356-018-1713-z

Sapkota, B., Dhaubhadel, R. (2002). Atmospheric turbidity over Kathmandu valley. Atmos. Environ. 36, 1249-1257. https://doi.org/10.1016/S1352-2310(01)00582-9

Schuster, G.L., Dubovik, O., Holben, B.N. (2006). Angstrom exponent and bimodal aerosol size distributions. J. Geophys. Res. 111, D07207. https://doi.org/10.1029/2005JD006328

Schutgens, N., Tsyro, S., Gryspeerdt, E., Goto, D., Weigum, N., Schulz, M., Stier, P. (2017). On the spatio-temporal representativeness of observations. Atmos. Chem. Phys. 17, 9761-9780. https://doi.org/10.5194/acp-17-9761-2017

Sharma, M., Kaskaoutis, D.G., Singh, R.P., Singh, S. (2014). Seasonal variability of atmospheric aerosol parameters over greater noida using ground sunphotometer observations. Aerosol Air Qual. Res. 14, 608-622. https://doi.org/10.4209/aaqr.2013.06.0219

Sharma, N.P. (2018). Variations of aerosol optical depth in Bhaktapur, Nepal. J. Inst. Eng. 13, 133138. https://doi.org/10.3126/jie.v13i1.20358

Sharma, V., Ghosh, S., Bilal, M., Dey, S., Singh, S. (2021). Performance of MODIS C6.1 Dark Target and Deep Blue aerosol products in Delhi National Capital Region, India: Application for aerosol studies. Atmos. Pollut. Res. 12, 65-74. https://doi.org/10.1016/j.apr.2021.01.023

Srivastava, P., Dey, S., Agarwal, P., Basil, G. (2014). Aerosol characteristics over Delhi national capital region: A satellite view. Int. J. Remote Sens. 35, 5036-5052. https://doi.org/10.1080/ 01431161.2014.934404

Stocker, T.F., Qin, D., Plattner, G.K., Tignor, M., Allen, S.K., Boschung, J., Nauels, A., Xia, Y., Bex, V., Midgley, P.M. (2013). IPCC, 2013: Climate Change 2013: The Physical Science Basis. Contribution of Working Group I to the Fifth Assessment Report of the Intergovernmental Panel on Climate Change. IPCC.

Tian, X., Gao, Z. (2019). Validation and accuracy assessment of MODIS C6.1 aerosol products over the heavy aerosol loading area. Atmosphere 10, 548. https://doi.org/10.3390/atmos10090548 
Tiwari, S., Tiwari, S., Hopke, P.K., Attri, S.D., Soni, V.K., Singh, A.K. (2016). Variability in optical properties of atmospheric aerosols and their frequency distribution over a mega city "New Delhi," India. Environ. Sci. Pollut. Res. 23, 8781-8793. https://doi.org/10.1007/s11356-0166060-3

Tiwari, S., Kaskaoutis, D., Soni, V.K., Dev Attri, S., Singh, A.K. (2018). Aerosol columnar characteristics and their heterogeneous nature over Varanasi, in the central Ganges valley. Environ. Sci. Pollut. Res. 25, 24726-24745. https://doi.org/10.1007/s11356-018-2502-4

Vijayakumar, K., Devara, P.C.S. (2012). Variations in aerosol optical and microphysical properties during an Indian festival observed with space-borne and ground-based observations. Atmosfera 25, 381-395.

Wei, J., Li, Z., Peng, Y., Sun, L. (2019). MODIS Collection 6.1 aerosol optical depth products over land and ocean: Validation and comparison. Atmos. Environ. 201, 428-440. https://doi.org/ 10.1016/j.atmosenv.2018.12.004

Winker, D.M., Tackett, J.L., Getzewich, B.J., Liu, Z., Vaughan, M.A., Rogers, R.R. (2013). The global 3-D distribution of tropospheric aerosols as characterized by CALIOP. Atmos. Chem. Phys. 13, 3345-3361. https://doi.org/10.5194/acp-13-3345-2013

Zhang, W., Xu, H., Zhang, L. (2019). Assessment of Himawari-8 AHI aerosol optical depth over land. Remote Sens. 11, 1108. https://doi.org/10.3390/rs11091108 